University of Michigan Law School

University of Michigan Law School Scholarship Repository

\title{
Criminal Procedure, the Burger Court, and the Legacy of the Warren Court
}

Jerold H. Israel

University of Michigan Law School, israelj@umich.edu

Available at: https://repository.law.umich.edu/book_chapters/97

Follow this and additional works at: https://repository.law.umich.edu/book_chapters

Part of the Criminal Procedure Commons, Fourth Amendment Commons, Law Enforcement and Corrections Commons, and the Supreme Court of the United States Commons

\section{Publication Information \& Recommended Citation}

Israel, Jerold H. "Criminal Procedure, the Burger Court, and the Legacy of the Warren Court." In Neither Conservative nor Liberal: The Burger Court in Civil Rights and Liberties, edited by F. G. Lee, 80-100. Malabar, Fla.: R. E. Krieger, 1983.

This Book Chapter is brought to you for free and open access by the Faculty Scholarship at University of Michigan Law School Scholarship Repository. It has been accepted for inclusion in Book Chapters by an authorized administrator of University of Michigan Law School Scholarship Repository. For more information, please contact mlaw.repository@umich.edu. 


\title{
chapter 5 "Criminal Procedure, the Burger Court, and the Legacy of the Warren Court"*
}

\author{
JEROLD H. ISRAEL**
}

Richard Nixon's criticism of the Warren Court during the 1968 presidential campaign centered largely on the Court's handling of cases involving criminal rights. According to candidate Nixon, the Court had gone much too far. It had twisted the Constitution to serve its own purposes, created a maze of legal technicalities that worked only to frustrate legitimate law enforcement efforts, and so weakened "the peace forces as against the criminal forces in this country" as to be largely responsible for the sharp rise in crime that had occurred in the sixties.

What had to be done, continued Nixon, was to appoint persons to the federal bench "who will interpret the Constitution strictly and fairly and objectively." Such "strict constructionist" judges could be expected not only to put and end to the creation of further legal rights for the accused, but might even trim back on some of the Warren Court "excesses." Decisions such as Mapp v. Ohio (1961), prohibiting the use of evidence obtained in violation of the Fourth Amendment's stricture against "unreasonable searches and seizures" and Miranda $v$. Arizona (1966), requiring the police to inform suspects of their constitutional rights before beginning any questioning were frequently cited by Nixon as examples of the type of decisions that should not have been made.

* Copyright @ 1977 Michigan Law Review. Reprinted by permission. This article is excerpted and printed without footnotes from the Michigan Law Review, Volume 75, pp. 1319-1425.

** Professor of Law, Univeristy of Michigan Law School. 
Nixon was not the only critic of Mapp and Miranda. Even certain supporters of the Warren Court had admitted that Mapp and Miranda were among the Court's "self-inflicted wounds." Miranda, for one thing, read more like a piece of legislation than a judicial opinion and Mapp recalled only too well Justice Cardozo's famous query: "Is the criminal to go free because the constable has blundered?"

Despite Nixon's victory in 1968 and his appointment of four justices to the Supreme Court, Mapp and Miranda have not been overruled.

The way in which they have survived and the manner in which the Burger Court has responded to other questions of criminal law and procedure give us another insight into the Burger Court.

The following excerpts are from a lengthy article by University of Michigan Law Professor Jerold H. Israel comparing the Burger and Warren Courts. The selection that follows focuses on his commentary on the Burger Court.

During the 1960s, the Warren Court's decisions in the field of criminal procedure were strongly denounced by many prosecutors, police of ficers, and conservative politicians. Some of these critics were careful in their description of the Warren Court's record. Others let their strong opposition to several of the Court's more highly publicized decisions destroy their perception of the Court's work as a whole. They charâcterized the Court's record in terms that can only be described as grossly exaggerated. They accused the Warren Court of ignoring totally the "balanced approach" to criminal procedure that had been taken by its predecessor, the Vinson Court. They claimed that the Warren Court's decisions were concerned only with the protection of the suspect. The Court had ignored, they argued, the fact that encroachment upon liberty could come from two sources; while the government interferes with our liberty when it misuses its law enforcement authority, as the Warren Court's opinions constantly noted, criminals also interfere with our liberty when they commit crimes that deprive us of life, liberty, and property. The Warren Court, the critics asserted, in seeking to deter governmental violations of individual liberty, had failed to give any weight to society's need to combat effectively this criminal element that poses an even greater danger to individual liberty. As a result, the critics claimed, the Warren Court had continuously imposed new limitations on police and prosecutors that had handcuffed those law enforcement officials in their efforts to control crime.

While there may have been some cause for the basic concerns of these critics, they so overstated their case as to create a grossly inaccurate and unfair image of the Warren Court. Fortunately, various civil libertarians, particularly those in academe, sought to set the record straight. They did not necessarily defend the 
Court. Indeed, many expressed concern over the quality of the Court's opinions. But they stressed that the critics had greatly exaggerated the extent of the Warren Court's departure from past precedent. The Court had not consistently ignored precedent; indeed, many of its decisions simply built upon past decisions. Neither had the Warren Court decisions looked solely to safeguarding the rights of the accused. The critics had ignored various decisions in which the Warren Court had accepted as constitutional the expansion of police authority to permit more effective law enforcement. Moreover, many of the "liberal" decisions cited by the critics were the product of a doctrinal shift that was related to individual rights generally and not just to the interests of the accused.

Today the tide has turned. The Court of the 1970's-the Burger Court-also is being denounced by various commentators, but now the challenge comes from the civil libertarians. Again some of the critics present a fair portrayal of the Court's record. But others are showing that gross exaggeration is a quality that can be shared by criticisms coming from both sides of the political spectrum. As with the Warren Court critics, many of the Burger Court critics are claiming that the Court has discarded precedent and tradition and has looked to only one aspect of the criminal justice process. They portray the Burger Court as steadily rejecting or "whittling down" the great civil libertarian advances of the Warren Court. They contend that the Burger Court is substituting narrow, technical interpretations of constitutional guarantees for the expansive interpretations of those guarantees adopted by the Warren Court. The current Supreme Court, they argue, shows only a "law and order" orientation-an interest in promoting the enforcement of the law without regard to protecting the rights of the accused. As they see it, the Burger Court has brought the criminal law revoluation of the 1960s to a halt and has, indeed, started a counterrevolution.

Criticism of this type appears to me to be as overstated as was much of the criticism of the Warren Court. The record indicates that the Burger Court has not undermined most of the basic accomplishments of the Warren Court in protecting civil liberties; neither has the Burger Court consistently ignored the interests of the accused. The current critics fail, I believe, to put in proper perspective what the Warren Court did and what the Burger Court has done (or even threatens to do). Certainly, to one who was a strong supporter of the Warren Court decisions in the criminal procedure field, the Burger Court may be somewhat disappointing. But it strikes me that the civil libertarians who describe the current Court as a disaster and a threat to the liberties of individuals are allowing their disappointment to blur their vision.

\section{Equality and the Burger Court}

Has the Burger Court departed substantially from the Warren Court's em- 
phasis upon equality? In two instances the Burger Court has refused to extend the Griffin concept. The first, Ross $\nu$. Moffit, rejected a proposed expansion of the right to appointed counsel on appeal. As noted earlier, the Warren Court held in Douglas v. California that the equal protection clause guaranteed the indigent defendant appointed counsel on appeal, but Douglas was limited specifically to an initial appeal automatically granied to the defendant under state law. In Ross the Burger Court held that Douglas would not be expanded to require appointed counsel to assist the indigent in preparing an application for a second-or thirdlevel appellate review that could be granted only at the discretion of the appellate court.

While the Warren Court might have been willing to extend Douglas to the Ross setting, the Ross ruling hardly placed a major limitation on the extension of the Griffin-Douglas doctrine. The Court's opinion emphasized that the decision of an appellate court to grant discretionary review rests largely on factors readily apparent from the record below, and therefore counsel's services are not nearly as significant in preparing the application for discretionary review as in presenting the initial appeal, which was treated in Douglas. This emphasis could readily be used to distinguish various other aspects of counsel's services that are much more commonly recognized as needed for meaningful access to the judicial process than "the somewhat arcane art of preparing petitions for discretionary review." Indeed, if a state supreme court or the United States Supreme Court exercised its discretion to grant a second-or third-level review, the equal protection clause still would appear to require that the indigent defendant be provided the assistance of counsel in presenting that appeal, since there is much greater need for counsel to present the merits on an appeal than to perform the narrower function involved in Ross.

In United States v. MacCollom, the Burger Court also refused to expand the Griffin analysis, but again the Court's ruling was quite limited. MacCollom held that it was constitutionally permissible to require as a condition for providing a free trial transcript on a collateral attack of a conviction, that the trial judge certify that the defendant's claim is not frivolous. The Court stressed, however, that the defendant could have obtained a transcript automatically on direct appeal, without trial court certification. It therefore seems unlikely that MacCollom will have significance aside from the special situation presented there, in which the defendant fails to appeal but subsequently seeks to obtain review by collateral attack.

In contrast to Ross and MacCollom, the Burger Court has approved substantial extensions of the equality theme in other contexts. Most significantly, in Argersinger $\nu$. Hamlin, the Court extended the Gideon ruling to require appointed trial counsel in all misdemeanor cases in which jail sentence is imposed. Moreover, the opinion of the Court left open the possibility of further expanding the right to counsel to encompass some cases in which jail sentences are not imposed. The practical impact of the Argersinger decision has been greater than Gideon. 
Not only are many more cases presented at the misdemeanor level, but there also were many more states that had not been appointing counsel in misdemeanor cases involving jail sentences prior to Argersinger than there were states that had not been appointing counsel in felony cases before Gideon.

The Burger Court also has approved other extensions of Gideon. In Coleman v. Alabama, the Court held that, although the state was not required to provide a preliminary hearing, it had to provide appointed counsel when such a hearing was available under state law-even in a jurisdiction that prosecuted by indictment so that the preliminary hearing bindover was not essential. In Gagnon v. Scarpelli, the Burger Court held that the indigent person also had a right to the assistance of appointed counsel in various probation and parole revocation proceedings. In Procunier $\nu$. Martinez, the Court held that a prisoner could not be kept from utilizing the legal assistance of law students and paraprofessionals.

Of course, these decisions do not move entirely in one direction. Liberals may complain that the Burger Court has not gone as far as the Warren Court would have gone on these issues. Maybe so, but maybe not. For example, in Gagnon, the Court admittedly did not hold that the indigent had an automatic right to counsel in all parole and probation revocation proceedings; rather, it held that the circumstances of the case would control under an analysis similar to the Betts v. Brady analysis that the Warren Court rejected in Gideon when it established an automatic right to appointed counsel at trial. Yet it should be noted that Justices Brennan and Marshall, who were both stalwarts of the liberal majority of the Warren Court, accepted the Gagnon standard.

In sum, considering Ross and MacCollom on the one hand, and Argersinger, Gagnon, and related cases on the other, the civil libertarian critics appear to be on less than firm ground if their broadside condemnation of the Burger Court's treatment of Warren Court precedent is meant to suggest that the Burger Court has undermined, or even generally refused to extend, the equality theme of the Warren Court.

\section{The Burger Court Record \\ Expansionism and the Burger Court}

There are at least two areas where the Burger Court has taken the lead from the Warren Court and adopted constitutional standards that are as protective of the individual as any the Warren Court would likely have adopted. The Court's interpretation of the sixth amendment right to counsel is one such area. I have already noted the Burger Court decisions in Argersinger and Coleman. In addition, there is Faretta $\nu$. California, where the Court held that the right to counsel included a supplemental right of the defendant to proceed prose at trial, even if he has no special legal knowledge or skill. 
Morrissey v. Brewer is another illustration of a ruling at least equally as expansive as many of the Warren Court rulings so warmly praised by civil libertarians. Indeed, Chief Justice Berger's opinion in Morrissey, in its extension of basic guarantees beyond the criminal trial, is reminiscent of the Warren Court's ruling in In re Gault. Morrissey required, as an element of due process, that significant hearing rights be afforded convicted persons in parole and probation revocation proceedings. Those hearing rights included not only a final hearing (in which the individual is entitled to written notice, disclosure of the evidence against him, a general right of confrontation, and a written statement by the factfinder), but also a preliminary hearing, which has to be provided promptly and must include a limited right to confrontation and notice.

Admittedly, in most areas the Burger Court's record does not show as consistent an emphasis on expansive interpretations as is found in Morrissey or in the right-to-counsel cases. Instead, the pattern of the Burger Court decisions tends to be more like that of the Warren Court in dealing with search and seizure problems; expansive interpretations of a particular constitutional guarantee have been adopted in some cases and rejected in others. Nevertheless, a close analysis of its decisions suggests that the Burger Court, on balance, has tended to favor somewhat expansive interpretations of constitutional guarantees in areas other than those involving police investigatory practices. The Court's decisions dealing with the right to a jury trial, double jeopardy, the right to a speedy trial, and the procedural forfeiture of constitutional objections are ... illustrative of the Court's record in areas marked by this mixed pattern of decisions.

\section{The Burger Court and Police Practices}

So far I have put to one side the Burger Court decisions regulating police investigatory practices. Undoubtedly these decisions have caused the most concern among civil libertarian critics of the Court. That concern is not unexpected. The Warren Court decisions relating to police practices rank high among those Warren Court decisions most revered by civil libertarians. Moreover, it is in this area that the Burger Court most clearly has departed from Warren Court precedents. The question remains, however, whether these Burger Court decisions have, as the critics suggest, largely eviscerated the Warren Court rulings. I believe that this has not been the case to date, and even those further cutbacks that are most likely to be made in the future should not have that effect.

\section{Police Interrogation}

The Miranda decision is the most highly publicized of all the Warren Court's criminal procedure decisions, and it is quite understandable that the civil libertar- 
ians look to its continuing vitality as a bellwether. In Miranda, the Warren Court required exclusion of a defendant's statement obtained through custodial interrogation unless he had been informed of his constitutional rights and of the possible adverse use of the statement (the so-called "Miranda warnings") and had voluntarily waived those rights before making the statement. Although the value of the Miranda ruling in effectively protecting the suspect's self-incrimination privilege is debatable, the decision has a symbolic quality that extends far beyond its practical impact upon police interrogation methods.

As noted previously, a major element of the Miranda decision-the equal treatment of the indigent-has not suffered at the hands of the Burger Court. Other aspects of the decision have, perhaps, been treated less well. Yet, the fact remains that Miranda still is the law of the land. Moreover, while its ramifications arguably have been narrowed, the Court has not cast doubt upon its basic premise that the defendant's right against self-incrimination applies to police custodial interrogation and not just to judicial compulsion of testimony by the threat of contempt. The Burger Court decisions most frequently noted by critics as undermining the Miranda ruling-Harris v. New York, Michigan v. Tucker, Michigan v. Mosley, and Oregon v. Mathiason-all have accepted that basic assumption.

Harris permitted the use of statements obtained in violation of Miranda to impeach the defendant's trial testimony. In the Tucker case, although the Court dealt with a special situation relating to retroactive application of Miranda, it clearly raised the possibility that the testimony of "tainted witnesses"-i.e., witnesses who were discovered because of a statement obtained in violation of Miranda -would not be excluded from evidence. In the Mosley decision, the Court held that a second interrogation session that occurred after a suspect initially refused to make a statement did not violate Miranda under the facts of that case. In the recent Mathiason case, the Court noted that not all interrogation conducted in a police station is necessarily "custodial interrogation" (the only type of questioning subject to Miranda).

While none of these cases adopted the expansive view of Miranda that the civil libertarians would have preferred, it also is true that Tucker, Mathiason, and perhaps even Mosley did not significantly detract from the basic Miranda ruling. The Court's conclusion in Mathiason that the suspect there had not been in "custody" might well have been reached by the members of the Miranda majority themselves. The suspect voluntarily came to the police station after a police officer requested that they meet; he was immediately informed that he was not under arrest; and he was allowed to leave following the close of the interview, even though he admitted committing the crime. While Justice Marshall dissented, his major point was that the Court should go beyond the custodial interrogation situation covered in Miranda and reach other interrogation situations as well.

Tucker, on the facts presented, also can be squared with Miranda. The issue 
before the Court concerned the application of the fruit-of-the-poisonous-tree doctrine to the testimony of a witness discovered as a result of police interrogation that had violated the Miranda requirements, but had been conducted before the Miranda case was decided. The Court held that, in light of the special problems raised by the application of Miranda to pre-Miranda interrogations, it was inappropriate to expand the impact of retroactive application by excluding the witness' testimony as well as the defendant's statement. However, language in Justice Rehnquist's majority opinion suggests that the Burger Court might not extend the poisoned-fruits doctrine to the tainted witness even where retroactive application is not involved. Assuming the Court eventually takes that position, would it necessarily be inconsistent with Miranda, especially where the police interrogation was not "designed specifically to obtain the names of witnesses? Some very "liberal" judges have acknowledged that the extension of the poisoned-fruits doctrine to subsequently discovered witnesses who willingly cooperate with the police is at least a very difficult question. While the witness may have been found through the defendant's statement, the possibility always exists that he might otherwise have come to the attention of the police if they had reached the point of methodically tracking down all persons who had even the remotest link to the victim of the accused. Indeed, even where the witness could not have been found by the most intensive investigation, the possibility remains that the witness eventually might have come forward on his own, perhaps in response to a general police request for assistance.

Mosley is similar to Tucker in that the decision was based on a rather unusual situation. The Court in Mosley upheld a second interrogation session after the defendant initially had refused to waive his rights and speak with officers. In rejecting the defendant's claim that Miranda prohibited a second attempt to obtain his waiver, the Court stressed the particular facts surrounding the second interrogation in Mosley. The second interrogation related to a separate crime and was initiated by an officer who apparently had not been aware of the defendant's initial refusal to cooperate. The officer had given complete Miranda warnings at the outset of the second session, and the defendant in no way indicated that he did not want to discuss the second crime. Admittedly, Justice White, in a concurring opinion, advanced an interpretation of Miranda that generally would allow repeated attempts to interrogate following an initial refusal, but his opinion was not joined by any of the other justices.

Unlike Mosley, Tucker, or Mathiason, Harris v. New York, the impeachment case, clearly did impose a significant limit upon the impact of Miranda. From the prosecutor's viewpoint, the consequences of a Miranda violation may be softened considerably by the ability to use the defendant's statement for impeachment purposes. A major value in obtaining a statement from a defendant, even where the defendant does not acknowledge commission of the offense, is the discovery 
provided regarding the defendant's likely trial testimony. While the defendant may shift somewhat from the explanation in his statement, the statement's availability for impeachment should keep the defendant's testimony close to that original explanation. Of course, if the statement is incriminating, then the Harris ruling is likely to have even more value from the prosecution's viewpoint. It may place the defendant in a position where he will be forced to take the chance involved in not testifying at all. If he takes the stand, the statement surely will be damaging notwithstanding the judge's admonition to the jury that they can consider the incriminating admissions only as to impeachment and not as substantive evidence.

Harris thus may be quite significant from the prosecutor's point of view. It is the police, however, who are largely responsible for determining how Miranda will be applied, and their immediate objectives focus more on justifying a decision to go forward with the prosecution than on the trial techniques eventually used to win the case. An admissible incriminating statement is of immense value in building the prima facie case needed to gain approval of the prosecution. A statement obtained in violation of Miranda, on the other hand, is likely to be given very little weight in determining whether a prosecution should be carried forward. The primary emphasis at this point must be on the adequacy of the prima facie case needed to get the case to the jury, not on certain tactical advantages that may be available if the defendant is forced to present a defense. Thus, from the police viewpoint, Harris does not substantially alter the impact of a Miranda violation.

It thus seems likely that, insofar as police compliance with Miranda is determined by the officer's calculated evaluation of the costs of violation, Harris should not influence significantly the officer's decision. Of course, Harris could have a substantial impact if it led prosecutors and others involved in police training programs to place less emphasis on compliance with Miranda, since police adherence to Miranda probably is influenced far more by the general thrust of that training than by calculated cost-benefit evaluations made by officers in individual cases. I am not aware, however, of any such change in training programs, and the continuing symbolic and practical significance of Miranda makes it most unlikely that Harris alone would encourage such a change.

\section{Search and Seizure}

Civil libertarians also have expressed considerable concern over the Burger Court's treatment of the fourth amendment. Indeed, the Court's decisions relating to the constitutionality of searches and seizures probably have been more sharply criticized than any other group of decisions involving the regulation of police practices. That criticism has centered primarily upon two sets of decisions, one defining the substantive standards for determining the reasonableness of a search 
or arrest and the other defining the scope of the exclusionary rule adopted in Mapp v. Ohio.

The resonableness of a search or arrest. In evaluating the Burger Court decisions dealing with the substantive standards for searches and seizures, it should be recalled that the Warren Court decisions in this area were varied in approach. On the one hand, the Warren Court refused to adopt expansive interpretations of the fourth amendment in several major decisions. In Warden $v$. Hayden, for example, the Court rejected the long-standing interpretation of the fourth amendment as prohibiting searches for "mere evidence." In Terry v. Ohio, the Court rejected the contention that frisks must be justified by probable cause. Ker v. California recognized that no-knock entry was permissible where needed to prevent the likely destruction of evidence. In McCray $v$. Illinois, the Court rejected a defense contention that, in challenging the probable cause allegedly supporting the search, it had the right to discover the name of the anonymous tipster who furnished information that led to the search. On the other hand, there were various decisions in which the Warren Court did adopt new, more rigorous standards for acceptable searches. Several cases rejected earlier opinions that had deemphasized the need for warrant authorization of a search whenever practicable. Most notably, Chimel v. California limited the permissible scope of a warrantless search incident to an arrest and thereby narrowed one of the most significant exceptions to the warrant requirement. At the same time, Spinelli v. United States applied stringent standards to the affidavit submitted on an application for a search warrant, thereby ensuring that the magistrate had an adequate factual foundation for determining whether to grant a warrant.

The Burger Court has on several occasions likewise adopted expansive interpretations of the fourth amendment. Thus, United States $v$. United States District Court held unconstitutional warrantless electronic surveillance of a domestic group accused of violence against the government. The Court held that the substantial governmental interest in a domestic security investigation could not override the traditional fourth amendment standards requiring warrant authorization of electronic surveillance. In Gerstein v. Pugh, the Court required alteration of the pretrial practice in many states by holding that the fourth amendment required a prompt post-arrest review of probable cause by a magistrate where an arrest was made without a warrant and the arrestee was still in custody or subject to extended restraint. Coolidge v. New Hampshire held invalid a rather unusual state practice that permitted a state attorney general to serve as a magistrate for the purpose of issuing a search warrant.

Decisions such as District Court, Gerstein, and Coolidge do not reflect the general trend, however. Viewed as a whole, Burger Court decisions judging the reasonableness of searches and seizures generally have refused to adopt new, more rigorous fourth amendment standards. Indeed, as critics have noted, the Burger 
Court decisions tend to grant the police more leeway than did the Warren Court decisions. The difference in the positions of the two Courts is not nearly as substantial, however, as the sharp criticism of the current Court might suggest.

In several major areas of search and seizure, it is far from certain that the often-criticized Burger Court decisions reach a conclusion contrary to that which the Warren Court might have reached. Thus, the Burger Court's decision upholding the issuance of a search warrant in United States $\nu$. Harris arguably may depart from the Warren Court ruling in Spinelli v. United States, but it should be noted that Justice White, who was one of the five Justices in the majority in Spinelli, also joined Harris. The divergence between the two rulings certainly is not extensive, and Harris arguably may be viewed as more consistent with the earlier Warren Court decision in Draper $v$. United States.

Similarly, while the Burger Court decisions dealing with probable-cause searches of automobiles arguably have failed to carry forward the Chimel emphasis upon obtaining warrant authorization whenever practicable, it seems likely that the Warren Court also would have viewed the Chimel rationale as inapplicable to most automobile searches. The leading Burger Court decision limiting the applicability of that rationale for automobile searches, Chambers $v$. Maroney, almost certainly would have been accepted by the Warren Court. Justice Stewart, who wrote Chimel, and Justices Douglas, Brennan, and Marshall, who had joined the Chimel opinion, all joined the Court's opinion in Chambers. They apparently had no difficulty with Chambers' extension of the "moving vehicle" exception to the warrent requirement (an exception that Chimel had not challenged) to uphold the warrantless search of an automobile conducted after the driver had been arrested and the automobile had been removed to the police station. Only Justice Harlan contended that such an extension was improper since temporary immobilization of the car would afford police ample opportunity to obtain a warrant before beginning their search.

Of course, Chambers, in turn, served as the foundation for Cardwell v. Lewis and Texas $v$. White, two cases that arguably further expanded the scope of the moving vehicle exception. Cardwell, in particular, may have undercut the Court's analysis in Coolidge v. New Hampshire, which suggested that the Chambers exception was limited to cases involving an unanticipated stopping of an automobile. but Coolidge, it must be remembered, was not a Warren Court decision but rather was a 1971 decision in which Justice Stewart's plurality opinion was supported by only three other Justices. Admittedly, Justice Stewart's opinion in Coolidge might have received majority support from the Warren Court of the 1962-1969 period, but, even under that assumption, Cardwell is the only one of the automobile search cases that clearly would have been decided differently by the Warren Court. Certainly, the Cardwell decision standing alone cannot be viewed as a dramatic departure from the Warren Court's position in Chimel, once Chambers is accepted as a valid exception to that position. 
The Burger Court's decision in Adams v. Williams presents similar difficulties in assessing its relationship to Warren Court precedent. Adams extended the Terry $v$. Ohio ruling on frisks to uphold forcible stops based on reasonable suspicion. Moreover, it did so where the individual's suspicious activity related solely to possessory offenses (narcotics and weapon possession), rather than to a forthcoming crime of violence as was suspected in Terry. Adams also held that the reasonable suspicion needed for a stop and frisk had been established when a person known to the officer approached the policeman on the street and reported the possessory offense but did not provide further corroboration. Notwithstanding the vigorous dissents of Justice Douglas (who had also dissented in Terry) and Justices Brennan and Marshall (who had joined Terry), it is certainly arguable that a Warren Court majority would have agreed with Adams. Justices Stewart and White, who joined Chief Justice Warren's opinion in Terry, also joined in the Adams decision, and the Adams case fits sufficiently within the basic rationale advanced in Terry to suggest that the remainder of the Terry majority might have reached a similar result. Although the Terry opinion did not rule on forcible stops, it posed an operating procedure that certainly suggested their validity. Similarly, the Terry rationale is in no way inconsistent with basing reasonable suspicion on information supplied by third persons without substantial corroboration by the officer's own observations.

More clear-cut deviations from the philosophy of the Warren Court arguably are found in several recent cases that permitted searches without requiring probable cause. In South Dakota v. Opperman, the Court upheld warrantless inventory searches of impounded automobiles. Opperman was based on a Warren Court precedent, Cooper v. California, but it is most unlikely that the Warren Court would have so extended Cooper. In United States v. Robinson and Gustafson v. Florida, the Burger Court upheld full searches of the person incident to a traffic arrest. Arguably, the Warren Court would have agreed with Justice Marshall's dissent in Robinson, which contended that no more than a frisk for weapons should be permitted since the officer clearly cannot expect to find evidence of the traffic offense on the person of the arrestee. Here again, however, the majority's position had substantial foundation in earlier opinions. Indeed, the majority opinions in Robinson and Gustafson may reflect a lesson suggested in several Warren Court opinions-the need for flat, simple rules that can easily be applied by police officers. Arguably, the Warren Court would have found such an approach inap. propriate where used to extend police authority, but it should be noted that Justice Stewart, who wrote Katz and Chimel, two of the leading "liberal" searchand-seizure opinions of the Warren Court, also joined the Robinson majority and concurred in the result in Gustafson.

Justice Stewart also wrote for the majority in Schneckloth v. Bustamonte, another case that arguably deviates from the policy of the Warren Court through its generous interpretation of a doctrine (search by consent) that validates searches 
without probable cause. Schneckloth ruled that, in establishing voluntary consent to a search following a street stop, the prosecution need not show that the individual had been made aware of his right to refuse to consent. The Warren Court presumably would have imposed a heavier burden on the prosecution, as urged in the dissenting opinions of Justices Marshall and Brennan.

Assuming that the decisions in Opperman, Robinson, Gustafson, and Schneckloth do depart from the approach of the Warren Court, how significant are these decisions in altering the protection of privacy afforded by the fourth amendment? Although all four permit searches without probable cause, they might not substantially broaden the search authority of the police beyond that which the Warren Court would have accepted. In Robinson and Gustafson, for example, it must be remembered that the dissenters would have permitted an automatic frisk of the arrested person, although not a full search. Moreover, as the dissenters also acknowledged, if the arrestee did not obtain his prompt release on station-house bail, he would have been subjected to an inventory search of his person (although the dissenters would not have permitted an inventory search so thorough as to examine the contents of the cigarette package that contained the contraband seized in Robinson). Finally, it also should be noted that Robinson and Gustafson apply only where the traffic stop involves a full-custody arrest, and Justice Stewart's concurring opinion in Gustafson leaves open the possibility that the fourth amendment might not permit full-custody arrests for all traffic violations.

The potential impact of Opperman is similarly limited by issues left open in the majority opinion. The inventory search involved there extended only to the interior of the automobile and an unlocked glove compartment. It is uncertain whether the same standard would be applied to a locked glove compartment or trunk. Although the car in Opperman was itself locked, it generally is much easier for someone to break into a locked car than into a locked trunk or glove compartment, and the police might have greater justification for removing all valuables from those areas that are readily accessible once the door locks are bypassed.

Like Robinson and Gustafson, the Schneckloth ruling on consent searches also was based upon a "street situation"-the noncustodial, on-the-street stop of an automobile. The Schneckloth majority held that, in such a situation, the prosecution does not have to establish that a driver, in granting his consent, was aware that he had a right to refuse the officer's request to search the car. In particular, the majority ruled that the police need not give warnings similar to those required by Miranda before requesting consent. It should be noted that the majority opinion does not relieve the prosecution of the burden of showing that the consent was voluntary. Neither does it render the driver's knowledge an irrelevant factor in determining voluntariness. The dissents by Justices Brennan and Marshall rejected the contention that the driver's awareness of the right to refuse to permit the search could be assumed, but, at the same time, neither dissent would have required that 
the police necessarily inform the driver of his right to refuse to give consent. The practical significance of the distinction between this position and that of the majority is difficult to determine. It is not clear, for example, whether the dissenters would permit the prosecution to establish knowledge by showing simply that the officer's phrasing of the request in itself suggested a right to refuse (e.g., where the officer said, "Will you give me your permission to search?")

No doubt, when decisions like Opperman, Robinson, and Scheckloth are added to decisions like Cardwell, the overall thrust of the Burger Court decisions is to grant the police far more flexibility than a civil libertarian is likely to view as acceptable. Yet the Court's approach is not so substantially different from that taken in many Warren Court decisions as to be characterized as a major departure from the. Warren Court's standard. Admittedly, there is a more substantial departure when the comparison is limited to the position taken by Chief Justice Warren and Justices Douglas, Brennan, Marshall, Fortas, and Goldberg. But, for much of the Warren period, no more than four of these Justices sat together, and they could not count on the ready support of Justice Black who of ten opposed an expansionist view of the fourth amendment. As a result, the Warren Court decisions in this area reflected a varied approach that was perhaps more "con" servative" than its approach in other areas. The Burger Court's fourth amendment decisions accordingly come closer in approach to the Warren Court rulings than do the decisions involving other police practices, where the addition of Justice Black gave the Warren Court majority greater leeway.

The scope of the exclusionary rule. As noted above, the civil libertarian critics also have expressed concern as to the Burger Court's treatment of a second aspect of the fourth amendment, the application of the Mapp $\nu$. Ohio exclusionary rule. So far, the Burger Court has done very little to restrict the Mapp ruling itself, which required the exclusion of unconstitutionally seized evidence only at the criminal trial. Indeed, in Brown v. Illino is, the Court specifically rejected an invitation to limit sharply the fruit-of-the-poisonous-tree doctrine, which determines the reach of the exclusionary rule in the trial setting. In Brown, the Court rejected the contention that the giving of the Miranda warnings automatically purged the taint of an illegal arrest, thereby permitting the admissibility of any subsequent confession of the arrestee to be judged without regard to the illegal arrest. The Court also made clear that Wong Sun v. United States, a Warren Court decision first holding an incriminating statement inadmissible as the fruit of an illegal arrest, was not limited to the facts of the case, which involved a statement made almost contemporaneously with the arrest.

On the other side, the Burger Court has rejected attempts to extend the exclusionary rule outside of the criminal trial, and it has overturned Warren Court precedent permitting a habeas corpus challenge to a conviction resulting from a trial in which illegally seized evidence was admitted. In United States v. Calandra, 
the Court held that the Mapp rule did not extend to grand jury proceedings, and a witness therefore could not object to grand jury questioning based on information obtained through a fourth amendment violation. While Justices Marshall, Brennan, and Douglas dissented, it is not clear that the majority's position would have been rejected by the Warren Court. That Court had accepted in other contexts Justice Black's view that the Court should be most reluctant to impose new legal limitations on grand jury proceedings since such limitations tend to cause delay and impede the grand jury's performance as a safeguard against unjust prosecutions.

In United States $v$. Janis, the Burger Court held that the exclusionary rule did not apply to an IRS assessment proceeding (a civil action) where the illegal search had been conducted by local police. Here, as Justice Stewart's dissent indicates, it is very likely that the Warren Court would have reached a different result. $\dot{A}$ major function of the exclusionary rule is to deter unconstitutional searches by denying police the use of illegally seized evidence, and the Janis ruling arguably might offer a counter-incentive to engage in such searches. However, Janis certainly should produce no more than a slight dent in the deterrent impact of the rule, since the primary concern of police remains the obtaining of criminal convictions, not possible IRS assessments.

A similar conclusion might be advanced with regard to Stone v. Powell. Here the Court clearly narrowed the exclusionary rule's scope but still left substantially intact its general effectiveness as a deterrent device. Stone held that, for all practical purposes, a fourth amendment objection could not be utilized to challenge collaterally a state conviction in a federal habeas corpus proceeding. The majority ruled that a federal court could not consider a habeas claim that unconstitutionally seized evidence was used at the petitioner's trial unless the petitioner had not been afforded an opportunity for "full and fair litigation" of his claim in the state courts. Stone rejected several Warren Court decisions that had considered fourth amendment claims on habeas petitions. Moreover, the Stone ruling arguably was inconsistent with the reasoning, though not the holding, of Fay $v$. Noia, one of the most celebrated opinions of the Warren era. Although Fay dealt with a collateral challenge to a conviction based on a coereced confession, the Fay opinion certainly suggested that federal habeas corpus should be available to challenge collaterally a state conviction on any constitutional error.

The Burger Court obviously is concerned about the sharp increase in habeas petitions since Fay and is seeking to restrict the scope of that opinion. Like Stone, Francis $v$. Henderson, discussed earlier, also narrowed the scope of collateral attack. From a civil libertarian viewpoint, the significance of decisions like Francis and Stone depends in large part on the importance of federal habeas review in achieving full recognition of the particular constitutional right in question. With respect to Stone and the fourth amendment, that significance should relate primarily to the degree to which federal habeas review strengthens the deterrent impact 
of the exclusionary rule beyond the deterrence that flows from the rule's application in the state courts. While people may disagree as to the precise significance of such federal habeas reinforcement, it surely has a comparatively minor bearing upon the rule's overall effectiveness as a deterrent.

The elimination of a federal collateral challenge based on the fourth amendment hardly is significant enough to suggest to police that the fourth amendment can be ignored. The primary focus of the police is on the everyday application of the exclusionary sanction by state courts. Of course, if the elimination of federal collateral attack led state trial courts to eviscerate fourth amendment standards, that stance probably would lead police, in turn, to pay considerably less attention to the fourth amendment. It seems most unlikely, however, that the Stone decision will encourage many state trial courts to vitiate the fourth amendment. The limited number of federal habeas reversals of state convictions suggests that a state trial judge with an inclination to ignore the fourth amendment is likely to be concerned primarily with reversal by a state appellate court, not by a federal habeas court. And the restraining influence of state appellate review should remain substantially intact notwithstanding Stone. Admittedly, Stone may have some impact upon those state appellate courts that have "liberalized" their views to fit that of the federal circuit court of appeals in their area, but such shifts in position are likely to be far too subtle to have any dramatic impact on trial court (or police) practices.

Taken together, the impact of Calandra, Janis, and Stone upon Mapp appears to be roughly similar to the impact of Mosley, Tucker, and Mathiason upon Miranda: while the Burger Court has refused to extend the Mapp ruling, neither has it cut back significantly upon the scope of that ruling. Indeed, as with Miranda, the intensity of civil libertarian criticism probably relates less to what the Court has done with the Mapp decision than to what the critics fear it will do in the future. Chief Justice Burger has suggested that perhaps Mapp simply should be overruled. He appears to stand alone, however, in suggesting total abandonment of the exclusionary rule. A more likely possibility is the modification of Mapp suggested by Justice White in Stone. There, Justice White urged that unconstitutionally seized evidence need not be excluded where the officer who seized the evidence was "acting in the good-faith belief that his conduct comported with existing laws" and had "reasonable grounds for [that] belief." While it appears that Justice White may have the support of three other Justices for adopting this modification the presence of the additional vote needed for a majority opinion is highly speculative. Let us assume, however, that Justice White's view does prevail. From the viewpoint of the civil libertarian, how much will have been lost? I suggest that the wound will be primarily to the civil libertarian's pride, not to the primary function of the exclusionary rule.

Of course, if one views the exclusion of evidence as an appropriate personal remedy for the person whose privacy has been invaded by an illegal search, then 
Justice White's approach has the basic defect of leaving some injured defendants without a remedy. But the Court traditionally has justified the exclusionary rule on two other rationales. Those rationales are the deterrence theory noted above and the theory that exclusion is necessary to maintain "the imperative of judicial integrity"-that courts cannot, consistent with their duty to uphold the Constitution, condone constitutional violations by permitting the fruits of those violations to serve as the basis for criminal convictions. When the exclusionary rule is viewed in light of these theories, Justice White's proposal does not seriously undermine the rule's basic functions, although it certainly does not strengthen the rule.

First, accepting arguendo the judicial-integrity rationale, Justice White's proposed modification would hardly place the Court in a more precarious position in maintaining that integrity than do various current rulings that also allow unconstitutionally seized evidence to be used in judicial proceedings. Consider, for example, the Warren Court ruling in Alderman v. United States, which held that a defendant lacks standing to object to the admission of evidence unconstitutionally seized from a third person. Under Walder $v$. United States, an early Warren Court opinion, unconstitutionally seized evidence also could be used under some circumstances for impeachment purposes. If the trial court's failure to exclude illegally seized evidence threatens its integrity by creating the "taint of [judicial] partnership in official lawlessness," it does so as readily under Alderman and Walder as under Justice White's proposed modification of Mapp. Indeed, that proposal, unlike Alderman, would at least draw distinctions according to the type of illegality and ensure condemnation of purposeful police illegality.

The impact of Justice White's proposed modification upon the deterrent function of the exclusionary rule is more troublesome. As even the most ardent supporters of the Warren Court acknowledge, the exclusionary rule has obvious limits as an effective deterrent device. The key to the rule's effectiveness as a deterrent lies, I believe, in the impetus it has provided to police training programs that make officers aware of the limits imposed by the fourth amendment and emphasize the need to operate within those limits. Justice White's exclusionary standard is not likely to result in the elimination of such programs, which are now viewed as an important aspect of police professionalism. Neither is it likely to alter the tenor of those programs; the possibility that illegally obtained evidence may be admitted in borderline cases is unlikely to encourage police instructors to pay less attention to fourth amendment limitations. Finally, Justice White's proposal should not encourage officers to pay less attention to what they are taught, as the requirement that the officer act in "good faith" is inconsistent with closing one's mind to the possibility of illegality.

I have considered so far the deterrent impact of the exclusionary rule only insofar as it serves what Professor Andenaes describes as a "general preventive ef fect." Arguably, the exclusionary rule also may have a significant impact as an 
immediate threat that deters illegal conduct in a particular case. Although we have come to place less reliance on special deterrence as a justification for imposing criminal sanctions, perhaps the Benthamite model makes sense as applied to the exclusionary rule, since the of ficer presumably operates in a less emotional, more rational fashion than most criminal offenders. Still, assuming that the rule does have a "special deterrence" effect, Justice White's proposed modification of the rule should not substantially alter that impact in those instances where it is most likely to be significant.

Where the of ficer recognizes that a search is clearly illegal, the special deterrence effect should not be diluted, since the officer also should recognize that the fruits of the search will be excluded under Justice White's proposal. The proposal is far more likely to have a bearing on those cases in which the officer views the legality of the search as a close question. In such a borderline case, the officer might proceed with the search on the ground that there is a good chance that the evidence will be admitted under Justice White's standard even if the search eventually is found to be illegal. Whether officers are likely to make such careful calculations is questionable. But assuming they do, will the of ficer's decision to proceed with the search in such borderline cases constitute a substantial change from current behavior? Even under the current Mapp rule, are not of ficers likely to proceed in cases they recognize as borderline, particularly where they are concerned that the evidence may not be available for seizure by the time they cure any potential legal difficulties? If the of ficer is astute enough to recognize the borderline nature of the search, he also should be astute enough to know that in a truly borderline case the issue of illegality of the search is likely to be compromised in the plea negotiation process, so that some prosecutorial benefit will be obtained from the search in any event.

Justice Brennan has raised still another objection to Justice White's approach: that it could retard the development of search and seizure law. In close cases, Justice Brennan suggests, the state and federal courts will not bother to decide whether the search was illegal, but simply will admit the evidence on the basis of the officer's good-faith effort supported by his reasonable belief as to the validity of the search. It is not clear, however, that Justice White's proposal would permit a court to follow that approach in deciding fourth amendment issues. The trial court readily could be required to determine whether there was, in fact, a violation of the fourth amendment before it begins to examine the officer's good faith. Justice White's approach, like the American Law Institute's similar proposal for modifying Mapp, apparently requires consideration of the "extent of [the of ficer's] deviation from lawful conduct"; the Court could readily hold that, to evalutate that factor, the trial court initially must determine how the requirements of the fourth amendment apply to the case before it.

In sum, the Burger Court has not yet modified Mapp as applied to the crimi- 
nal trial. Moreover, if it should do so, the most likely modification-Justice White's approach-can hardly be described as a threat to the very heart of the rule.

Looking to the area of police practices as a whole, the Burger Court decisions certainly provide a more substantial basis for civil libertarian criticism than the Court's decisions in other areas of criminal procedure. Yet, even in this area, when one considers decisions such as Gerstein, United States $\nu$. United States District Court, and Brewer and notes the limited scope of decisions such as Mosley and Schneckloth, it seems to be stretching the record to say that the Court has followed a def inite pattern of "looking at defendants' rights as narrowly as possible without overruling past decisions." Certainly, statements of utter despair concerning the removal of constitutional restraints upon police can hardly be justified by the Court's decisions to date. Much of that despair undoubtedly relates to anticipated decisions, but here again, based on reasonable expectations, the critics' concerns appear overstated. While it remains possible that the current majority will overrule Miranda and Mapp, the Court's recent decisions, and the opinions of the individual Justices, suggest an approach more likely to be directed toward modifications that will not undermine the basic strength of either Miranda or Mapp.

\section{THE BURGER COURT IMAGE}

Where then does this analysis leave us when we review the record of the Burger Court as a whole? Even the most zealous civil libertarian, I suggest, cannot properly characterize the Court's decisions as reflecting an absolute, or even consistent, opposition to an expansionist interpretation of the Bill of Rights' guarantees. Neither can the Court properly be charged with having destroyed, or even having seriously threatened to destroy, the basic legacy of the Warren Court. The selective incorporation doctrine and the concept of equal treatment of the indigent remain firmly implanted in the governing law. Similarly, in determining the scope of individual Bill of Rights' guarantees, the Court has followed the expansionist tendencies of the Warren Court in several areas. Decisions like Argersinger, Faretta, Morrissey, Ashe, Waller, and Taylor are fully in keeping with the Warren Court tradition. In other areas, the Court's decisions may not have gone as far as the Warren Court would have gone, but they are not far behind. The Barker decision, for example, may not be as far-reaching as the civil libertarians would have liked, but it has put pressure on the states to make sub. stantial legislative efforts to guarantee a speedy trial to defendants.

Of course, the Burger Court decisions do not move entirely in one direction. There are various cases in which expansionist interpretations have been rejected, and in the area of police practices the Burger Court clearly seems intent upon cutting back upon, though not necessarily overruling, some of the key Warren Court decisions. Yet, taken as a whole, the Burger Court record certainly does not suggest that the Court values effective law enforcement over all else. Indeed, its 
decisions consistently reject an approach that would permit the state to override the interests of the accused whenever such action could be supported by a rational state interest. A Court that started from Judge Learned Hand's assumptions that "the accused has every advantage" at trial and that the primary defect in the current process is the "archaic formalism and watery sentiment that obstructs, delays, and defeats the prosecution of crime" surely would have rejected the defense claims recognized in such cases as Warclius, Faretta, and Brooks.

The civil libertarian critics also must take into account the fact that the issues presented to the Burger Court have a somewhat different quality than many of the issues presented to the Warren Court. Although the Warren Court had to treat close questions in several of its most prominent decisions, it also dealt with a significant number of cases that were rather easily resolved once it was decided that the particular constitutional provision applied to the states through the fourteenth amendment. The Burger Court has not had the opportunity to "bolster" its record in the protection of civil liberties with many cases like Pointer v. Texas, Duncan v. Louisiana, Klopfer v. North Carolina, and Benton v. Maryland. Of course, even if one discounts such decisions, the remaining Warren Court decisions obviously show a more substantial leaning toward an expansive interpretation of individual safeguards than do the Burger Court decisions, particularly in the area of police practices. But the weakness in the Burger Court's record from a civil libertarian's point of view may exist only as compared with the performance of the Warren Court. Even there, the current Court's record is quite comparable to the record of the Warren Court before 1962, when Justice Goldberg replaced Justice Frankfurter. The Burger Court certainly has made far greater advances in protecting the interests of the accused than were made by the Vinson Court, even when appropriate weight is given to the narrow and scarce precedents upon which the Vinson Court could build. Moreover, while civil libertarians have called our attention to several state courts that recently have imposed more rigorous limitations on police or prosecutors pursuant to state constitutions, the fact remains that the Burger Court is ahead of most state courts in protecting civil liberties, as illustrated by the significant change in state practice required by decisions like Argersinger, Ashe, Waller, and Morrissey.

There remains the contention that the harsh civil libertarian criticism of the Burger Court is justified not so much by what the Court has done, but by what it has said. Even when defense claims are upheld by the Burger Court, it is argued, the opinions raise questions that encourage state court evasion of the Court's own decisions; considerations are balanced so neatly that each case appears limited to its facts; and doubts never before entertained are expressed about the future course of precedent. These qualities undoubtedly are found in several of the Court's leading opinions, but almost all of those are opinions dealing with Mapp, Miranda, and Fay. Other opinions, such as Argersinger and Morrissey, clearly look toward 
further extension of constitutional guarantees. Moreover, in several cases, the prospect of future rejection of Warren Court decisions has been stressed primarily by dissents, usually by Justice Brennan, predicting the Court's eventual expansion of a minor exception to a Warren Court ruling into a total rejection of the earlier precedent. Civil libertarians and lower courts must recognize that Justice Brennan's cries of "wolf" have come forth so frequently that some Justices in the majority apparently have decided simply to ignore them. The absence of a response does not necessarily mean that Justice Brennan is accurately predicting the majority's intentions.

Of course, while the style of the Burger Court opinions on the whole is not negative, it also is not very positive. Opinions that openly balance interests on both sides and rely upon multifaceted standards do not "glorify" individual rights or even boldly call to the public attention major civil liberties issues. In this respect, the Burger Court lags far behind the Warren Court. The Warren Court opinions brought to the attention of the American people the important lesson that the observance of procedural safeguards is a significant indicator of the strength of our liberty. They spoke clearly and strongly on the need to keep law enforcement itself under the rule of law. As a result, the legitimacy of law enforcement practices became a subject of public debate rather than a concern only to the readers of Commentary or Harpers.

The Burger Court opinions, while obviously less helpful from the viewpoint of civil libertarians, still are not without potential value for their cause. Today, the public appears to be far more concerned about controlling crime than protecting the rights of suspects. Polls suggest that many people favor measures designed to "crack down" on crime, including some measures that would limit the rights of the accused. The Burger Court opinions suggesting possible future restrictions of Mapp or Miranda have been used by supporters of such conservative measures to promote their public acceptance. But neither the record of the Court nor the tenor of its majority opinions, taken as a whole, really supports a broad movement towards restricting the protections afforded the accused. Many civil libertarians might be well advised to examine the current Court's record carefully and to push aside the fact that Richard Nixon appointed four members of the current court. If they did so, they might find that their true interests lie in dropping their wholesale attacks on the Burger Court and in attempting instead to attract public attention to the various decisions of that Court that stress the continuing need to safeguard the basic rights of the accused. 